\title{
Neonatal oxygen therapy in low- and middle-income countries: a pragmatic review
}

\author{
Jon Zelasko', Moshood O Omotayo², Sara K Berkelhamer ${ }^{3}$, Susan Niermeyer ${ }^{4}$, Lily Kak ${ }^{5}$ Smita Kumar ${ }^{5}$, Pavani K Ram ${ }^{6}$ \\ 1 Jacobs School of Medicine at the University at Buffalo, Buffalo, New York, USA, ${ }^{2}$ School of Public Health and Health Professions, University at \\ Buffalo, Buffalo, New York, USA, ${ }^{3}$ Department of Pediatrics, University at Buffalo, Buffalo, New York, USA, ${ }^{4}$ USAID, Washington, District of Columbia, \\ USA; University of Colorado School of Medicine and Colorado School of Public Health, Aurora, Colorado, USA, 5 USAID, Washington, District of \\ Columbia, USA, 6 School of Public Health and Health Professions, University at Buffalo, Buffalo, New York, USA; USAID, Washington, District of \\ Columbia, USA \\ Keywords: developing countries, oxygen therapy, neonates \\ https://doi.org/10.29392/001c.12346
}

\section{Journal of Global Health Reports}

Vol. 4, 2020

\section{Background}

We assessed and summarized the peer-reviewed literature on the state of neonatal oxygen therapy in low and lower-middle income countries.

\section{Methods}

A literature search was performed in 3 online databases (Pub Med, EMBASE, CAB Global Health) and amongst USAID's Service Provision Assessment (SPA) reports for publications pertaining to neonatal oxygen therapy in low and lower-middle income countries over the past 10 years (2007-2017).

\section{Results}

Our search yielded 474 records, of which 26 were relevant and included in the review. Maintenance and indirect costs associated with the procurement of oxygen may constitute barriers to oxygen supply. The quality of therapy provided to neonates was affected by factors including a lack of necessary equipment at neonatal healthcare facilities and high indirect costs associated with the procurement of oxygen. Pulse oximeters used for monitoring of oxygen therapy were available in healthcare facilities, but there is scant data on the frequency of that monitoring. There are some hospitals that deliver neonatal oxygen therapy without any necessary monitoring equipment. Prevalence of retinopathy of prematurity among neonates with risk factors ranged from 11.9-47.2\%, which is notably higher than published rates in neonates of similar gestational age being treated in high-income countries.

\section{Conclusion}

There is a lack of data that provides direct estimates of availability of neonatal oxygen equipment and related clinical applications of oxygen therapy across health systems, particularly around the usage and availability of necessary monitoring equipment. Attention to the maintenance of oxygen and ancillary equipment for neonates and quality improvement initiatives to promote adherence to those guidelines can reduce the morbidity and mortality burden among neonates in low and lower-middle income countries.

There has been remarkable success in reducing mortality among children less than 5 years old in recent decades resulting in a dramatic $62 \%$ reduction in childhood mortality in the time period from 1990 to $2016 .{ }^{1}$ However, reductions in neonatal mortality have lagged behind, declining only $49 \%$ in that same time period. ${ }^{1}$ Currently, neonatal mortality accounts for $46 \%$ of under-five deaths, with $99 \%$ of these deaths occurring in low and middle-income countries (LMIC). ${ }^{1}$ Increasing utilization of healthcare services as a means to improve child health has been a core component of global health and development. ${ }^{2}$ In recent decades, there has been improvement in the rates of antenatal care, skilled attendance at birth, and postnatal care in low and middleincome countries. ${ }^{3}$ However, increased healthcare utilization is often not accompanied by high quality of care, limiting the impact on neonatal health outcomes. ${ }^{3}$

Oxygen therapy, one of the most widely used neonatal care interventions in high-income countries, is an essential part of emergency neonatal care. ${ }^{4}$ It is used for treatment of many important causes of neonatal morbidity that result in hypoxemia, including respiratory distress syndrome, asphyxia, infection, and other primary lung diseases. ${ }^{5}$ Howev- 
er, inappropriate use of oxygen therapy in neonates can also lead to serious adverse consequences. ${ }^{6}$ In the post-World War II era, retinopathy of prematurity was a leading cause of blindness in Europe and North America, with unmonitored oxygen therapy as the major risk factor. ${ }^{7}$ Evidence suggests that another epidemic of retinopathy of prematurity is occurring due to widespread unmonitored oxygen therapy in premature infants in low and low-middle income countries. $^{8}$

Developing and implementing global newborn health strategies warrants a broad understanding of the state of neonatal oxygen therapy in low and middle-income countries. In our pragmatic review, we aim to assess and summarize the peer-reviewed literature on the state of neonatal oxygen therapy in low and low-middle income countries between 2007 and 2017, as well as identify key research and programmatic gaps relating to the quality of neonatal oxygen therapy in this environment.

\section{METHODS}

\section{SEARCH STRATEGY}

We conducted a literature search in three online databases (Pub Med, EMBASE, CAB Global Health) and amongst USAID's country-based sampled health facility assessments, known as "service provision assessments." 9 We used the Donabedian model of healthcare quality to guide and organize our review (Figure 1). ${ }^{10}$ Based on the dimensions of quality described in the Donabedian model, we focused the review on the availability of physical equipment and consumables needed for neonatal oxygen therapy, clinical practices relating to neonatal oxygen therapy, and the outcomes and complications of neonatal oxygen therapy.

To reflect the current state of neonatal oxygen care, we limited our search to publications in the previous 10 years before our search was conducted (2007-2017). We limited the countries included in the search to low-income and lowmiddle income countries according to the 2016-2017 World Bank country groups. Search terms reflected equipment and supplies needed for oxygen therapy (pulse oximetry, oxygen cylinders, etc.), associated complications (retinopathy of prematurity, bronchopulmonary dysplasia, etc.), other terms that select for neonates (neonate, newborn, etc.), and terms identifying the countries of our search. The search terms used for the search of the PubMed dataset are provided in Figure S1 in the Online Supplementary Document. Articles that provided information on clinical practice and training, physical equipment including consumables such as electricity and oxygen source, and outcomes of oxygen therapy were included. Exclusion criteria were: (a) research on animal rather than human subjects, (b) entries in languages other than English, (c) countries not categorized as low or low-middle income, (d) study not providing information specific to neonates, (e) study not describing the availability or use of physical equipment and materials needed for oxygen therapy, the clinical practice of neonatal oxygen therapy, or the outcomes of neonatal oxygen therapy, (f) publications focused on invasive forms of mechanical ventilation, and (g) full text not available.

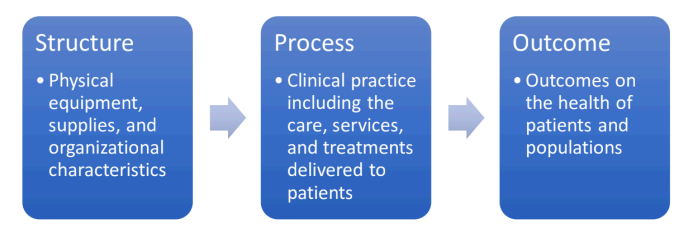

Figure 1. Donabedian Model of Healthcare Quality. ${ }^{10}$

\section{LITERATURE SEARCH}

We identified 474 records from the initial search of the databases and an initial search of the previously described USAID Service Provision Assessments. After removal of the duplicates and reviewing the titles for country relevance (low or low-middle income country), and time period (2007-2017), we selected 132 records. We reviewed abstracts of the selected records to ascertain information on location, time period, and relevance of information for the neonatal age group; 100 publications met the eligibility criteria for review of the full publication. We then reviewed the full text of the selected abstracts to determine whether inclusion criteria were met. Excluded publications were coded according to the reason for exclusion and appropriate data was extracted from the 26 entries that met the inclusion criteria. The extraction process that followed focused on information in the following categories: general study characteristics (title, author, year, location, and study design), physical equipment, clinical practice, clinical outcomes, summary, and bias assessment.

\section{RESULTS}

For each of the dimensions of quality described in the Donabedian model (structure or physical equipment, process or clinical practice, and outcomes) we have summarized our results in summary tables (Table 1, Table 2 and Table 3 ).

\section{A) PHYSICAL EQUIPMENT OF NEONATAL OXYGEN THERAPY}

For the structural dimension (physical equipment and consumables), we examined five categories of provisions needed for appropriate neonatal oxygen therapy: (a) availability and use of oxygen, mode of oxygen storage, and general supplies needed for oxygen therapy; (b) materials used to modify the oxygen being provided (e.g. oxygen blenders, flow splitter, heaters, humidifiers, and continuous positive airway pressure (CPAP) devices); (c) patient interface with the oxygen (eg. nasal prongs, nasal cannula, nasopharyngeal cannula, oxygen hood, or face mask); (d) equipment used in the monitoring of oxygen therapy (pulse oximeters or multi-parameter monitors); and (e) maintenance and repair of the equipment. The findings of this review on physical equipment used in the provision of neonatal oxygen therapy are summarized in Table 1. 
Table 1. Physical equipment summary

\begin{tabular}{|c|c|c|c|c|}
\hline Author & $\begin{array}{l}\text { Reference } \\
\text { Year }\end{array}$ & Location & Health Care Facility & Information on Physical Equipment Obtained \\
\hline \multicolumn{5}{|l|}{ Southern Asia: } \\
\hline Bhatti & 2012 & India & Referral Hospital (1) & bCPAP and jet CPAP with binasal prongs used, gas heated and humidified \\
\hline Das & 2011 & Pakistan & University Hospital (1) & Hood oxygen, nasal prongs, pulse oximeter used \\
\hline Koti & 2009 & India & Referral Hospital (1) & bCPAP with binasal prongs used \\
\hline Sen & 2009 & India & District Hospital (1) & Oxygen concentrator, central oxygen, individual pulse oximeters installed and used \\
\hline Tagare & 2013 & India & $\begin{array}{l}\text { Tertiary Care Hospital } \\
\text { NICU (1) }\end{array}$ & bCPAP and vCPAP with binasal prongs used, binasal prongs available in "appropriate" sizes \\
\hline Sathar & 2017 & India & Referral Hospital (1) & Pulse oximeter used \\
\hline Shah & 2015 & Nepal & $\begin{array}{l}\text { NICU - Referral Hospital } \\
\text { (1) }\end{array}$ & Method of delivery oxygen hood or mask. \\
\hline Kandraju & 2012 & India & Level III NICU (1) & bCPAP with binasal prongs, hood oxygen used \\
\hline Rohit & 2014 & India & $\mathrm{NICU}(1)$ & nCPAP, high flow nasal cannula, pulse oximeter used \\
\hline Sanghi & 2014 & India & $\begin{array}{l}\text { Infants referred from level I } \\
\text { and II nurseries }\end{array}$ & Author notes referral hospitals all had a paucity of saturation monitors and oxygen blenders \\
\hline \multicolumn{5}{|l|}{ Sub-Saharan Africa: } \\
\hline Kawaza & 2016 & Malawi & $\begin{array}{l}\text { Main Referral Hospital in } \\
\text { Country (1) }\end{array}$ & Oxygen concentrator and bCPAP used \\
\hline Hundalani S.G. & 2015 & Malawi & $\begin{array}{l}\text { Main Referral Hospital in } \\
\text { Country (1) }\end{array}$ & Oxygen concentrator, bCPAP, pulse oximeter used - notes that "many district hospitals in Malawi do not have flow splitters" - Nasal cannula used \\
\hline Heuvel & 2011 & Malawi & $\begin{array}{l}\text { Main Referral Hospital in } \\
\text { Country (1) }\end{array}$ & Oxygen concentrator and air compressor, bCPAP with binasal prongs used and installed - prongs reusable and at least one in neonatal size \\
\hline $\begin{array}{l}\text { Service Provision } \\
\text { Assessment }\end{array}$ & 2010 & Kenya & Nationwide Survey & Country-wide survey $-37 \%$ of newborn care facilities had oxygen $-75 \%$ of hospitals providing newborn care \\
\hline Adio & 2014 & Nigeria & Tertiary Care Hospital (1) & Pulse oximeter used \\
\hline \multicolumn{5}{|l|}{ Northern Africa: } \\
\hline Osman & 2015 & Egypt & University Hospital (1) & nCPAP with binasal prongs, blender, flow meter, and humidified and heated HFNC used - binasal prongs available in 5 different sizes \\
\hline \multicolumn{5}{|l|}{ Oceania: } \\
\hline Sa'avu & 2014 & $\begin{array}{l}\text { Papua } \\
\text { New } \\
\text { Guinea }\end{array}$ & Rural District Hospitals (5) & $\begin{array}{l}\text { Oxygen cylinders used pre-intervention - Oxygen Concentrators used post-intervention; Flow splitter and monitors installed; Pulse oximeters available only } \\
\text { in operation rooms - no hospitals had neonatal probes for pulse oximeters }\end{array}$ \\
\hline
\end{tabular}




\section{PHYSICAL EQUIPMENT: AVAILABILITY OF OXYGEN AND OXYGEN STORAGE}

One Service Provision Assessment and five peer reviewed publications provided information on service readiness and availability of neonate-specific oxygen therapy at health facilities in low and low-middle income countries. ${ }^{11-16}$ Three of the five publications independently described oxygen concentrators in use at a single referral hospital, Queen Elizabeth Central Hospital in Malawi, over different time periods with Heuvel et al. describing the installation of the oxygen concentrators in 2011 and their use at points during the subsequent three years following installation. ${ }^{11-13}$

Sa'avu et al. assessed the availability of resources needed for high quality treatment of childhood pneumonia and neonatal illnesses before a quality improvement intervention in five rural district hospitals in Papua New Guinea, and was the only article to provide information about electricity supply, cost, and logistical issues pertaining to neonatal oxygen therapy. ${ }^{16}$ Oxygen cylinders were used as the source of oxygen by all hospitals and the most commonly cited barriers to oxygen availability were a lack of funding for transport of oxygen as well as problems that occurred in the transport of oxygen such as road closures due to local conflicts and landslides. ${ }^{16}$

The Service Provision Assessment conducted in 2010 in Kenya surveyed health care facilities that provide care for neonates, including neonatal oxygen therapy. ${ }^{14}$ Assessors reported that $75 \%$ of all hospitals (a definition encompassing district hospitals, provincial hospitals, and referral hospitals) and $37 \%$ of all facilities (hospitals, health centers, maternities, clinics, and dispensaries) offering labor and delivery services had an oxygen source available. ${ }^{14}$

\section{PHYSICAL EQUIPMENT: MATERIALS USED TO MODIFY THE OXYGEN FLOW, HUMIDITY, PRESSURE, OR CONTENT}

Most of the information in the literature involving material used to modify the oxygen administered to neonatal patients was related to continuous positive airway pressure devices (CPAP). Eight publications described some form of continuous positive airway pressure device (bubble CPAP, nasal CPAP, and a variable flow jet CPAP) in use as a part of the description of a related clinical trial or observational study. ${ }^{11,12,17-22}$ These studies all took place at neonatal intensive care units or referral hospitals with five studies from India, two from the same hospital in Malawi, and one from Egypt. ${ }^{11,12,17-22}$

Two randomized controlled trials of high-flow nasal cannula utilized equipment to heat and humidify oxygen, but no publications addressed the provision of clean water for such humidifying units. ${ }^{17,20}$ Three studies provided indication of the installation or use of flow splitters, ${ }^{11,16,20}$ but Hundalani et al., mentioned that "many district hospitals in Malawi do not have flow splitters that would allow the delivery of < $1 \mathrm{~L} / \mathrm{min}$ oxygen" in the discussion of their 2015 study. ${ }^{12}$ Finally, Osman et al., provided the only description of oxygen blenders and flow meters in the reviewed literature. 20

\section{PHYSICAL EQUIPMENT: PATIENT INTERFACE DEVICES}

Nine publications provided information on patient interface devices with six describing studies completed in South Asia, two conducted in Malawi, both at Queen Elizabeth Central Hospital, and one conducted in Egypt; all studies described referral hospitals. ${ }^{11,12,17-23}$ The most common patient interface was nasal prongs used in conjunction with a CPAP device (three articles representing three hospitals in India, one in Pakistan, one in Egypt, and one in Malawi). ${ }^{11,12,17-20,22}$

Of the nine publications with information on patient interface devices, only three provided some description of the sizes of nasal prongs available, as neonatal sizes are generally accepted as necessary to administer oxygen to neonates with such an interface. Tagare et al. described the availability of "appropriate sizes" of nasal prongs at a neonatal intensive care unit (NICU) in India and Osman et al. described the availability of five different sizes of nasal prongs at a university hospital in Egypt in the methods section of their respective randomized control trials. ${ }^{20,22}$ Meanwhile, Heuvel et al. described nasal prongs being available in both infant and neonatal size at Queen Elizabeth Hospital in Malawi in 2011. ${ }^{11}$

Heuvel et al. also indicated that the binasal prongs were reusable and that the standard protocol was to clean the prongs with soap and water followed by alcohol following each use. ${ }^{11}$ No other publications addressed nasal cannula, nasal prong, or tubing replacement.

\section{PHYSICAL EQUIPMENT: MONITORING EQUIPMENT}

A total of 10 publications reported data on equipment used in the monitoring of oxygen delivery, describing 6 studies conducted in Southern Asia, 3 conducted in Africa, and 1 in Southeast Asia. The publications in Africa were set in a tertiary care hospital and the main referral hospital in Malawi. 11,12,15-17,21,23-26 The publications from South Asia reflected studies conducted at tertiary care hospitals or neonatal intensive care units in India and Pakistan. 11,15,17,21,23,26 The only study from Western Pacific Region was conducted in five rural district hospitals in Papua New Guinea. ${ }^{16}$

Two of the publications reported on situations where pulse oximetry, or other equivalent monitoring device, was unavailable or insufficient. In a 2014 study describing the features of 15 infants with aggressive posterior retinopathy of prematurity who had been referred to an Indian tertiary care hospital from lower level nurseries, Sanghi et al. found that "all infants received unmonitored oxygen for prolonged duration." 25 Sa'avu and co-workers specifically assessed the availability of resources needed for quality care of childhood pneumonia and neonatal illnesses before a quality improvement intervention in five rural district hospitals in Papua New Guinea. ${ }^{16}$ They found that although all five hospitals had pulse oximeters, they were available only in operating rooms and used by anesthesiologists, and not for sick neonates. ${ }^{16}$

All other reports describing the use of pulse oximetry were not from publications specifically examining use in the population, but rather from publications evaluating the 
Table 2. Clinical practice of neonatal oxygen therapy summary table

\begin{tabular}{|c|c|c|c|c|}
\hline Author & $\begin{array}{l}\text { Reference } \\
\text { Year }\end{array}$ & Location & $\begin{array}{l}\text { Health } \\
\text { Care } \\
\text { Facility } \\
(\mathrm{n}=)\end{array}$ & Conclusions \\
\hline \multicolumn{5}{|c|}{ Southern Asia: } \\
\hline Kumar & 2011 & India & $\begin{array}{l}\text { Tertiary } \\
\text { Care } \\
\text { Hospital } \\
\text { (1) }\end{array}$ & $\begin{array}{l}\text { Infants were weaned from NIPPV once stable at minimum settings for } 12 \\
\text { hours, no mention of trial on ambient air }\end{array}$ \\
\hline Sathar & 2017 & India & $\begin{array}{l}\text { Referral } \\
\text { Hospital } \\
\text { (1) }\end{array}$ & $\begin{array}{l}\text { Goal SpO2 between } 93-95 \% \text { during therapy, pulse oximetry monitoring } \\
\text { was continuous }\end{array}$ \\
\hline Rohit & 2014 & India & $\begin{array}{l}\mathrm{NICU} \\
(1)\end{array}$ & nCPAP started at $\mathrm{FiO} 2$ of .4 for neonates with $\mathrm{RDS}$ and $\mathrm{GA}<37$ weeks \\
\hline \multicolumn{5}{|c|}{ Sub-Saharan Africa: } \\
\hline Heuvel & 2011 & Malawi & $\begin{array}{l}\text { Main } \\
\text { Referral } \\
\text { Hospital } \\
\text { in } \\
\text { Country } \\
\text { (1) }\end{array}$ & $\begin{array}{l}\text { Of } 25 \text { children overall who met inclusion criteria for CPAP during the } 7 \\
\text { wk introductory period of the machine; } 5 \text { received therapy due to the } \\
\text { machine being unavailable or clinical error; } 6 \text { neonates received CPAP } \\
\text { whom were eligible for the therapy during the same time period; after } \\
\text { introductory period frequency of CPAP use declined - stated protocol to } \\
\text { reuse nasal prongs after washing with soap and water follow by an } \\
\text { alcohol disinfectant }\end{array}$ \\
\hline Adio & 2014 & Nigeria & $\begin{array}{l}\text { Tertiary } \\
\text { Care } \\
\text { Hospital } \\
\text { (1) }\end{array}$ & Goal SpO2 of $90-95 \%$ reported \\
\hline
\end{tabular}

NIPPV - nasal intermittent positive pressure ventilation, CPAP - continuous positive airway pressure, nCPAP - nasal continuous positive airway pressure, SpO2 - oxygen saturation, FiO2 - fraction of inspired oxygen

outcomes of oxygen therapy in selected centers or publications detailing the installation of new oxygen therapy equipment. ${ }^{11,12,15,17,21,23,24,26}$ All of these publications indicated that pulse oximetry was available in the specified health facility in the course of the evaluation. $11,12,15,17,21,23,24,26$

Only one publication reported information on neonatalspecific probes or the reuse or replacement of pulse oximetry probes. Sa'avu et al., again reporting on five district hospitals in Papua New Guinea in a study published in 2014, found that none of the hospitals $(0 / 5)$ had neonatal sensor probes for their pulse oximeters. ${ }^{16}$

\section{PHYSICAL EQUIPMENT: MAINTENANCE AND REPAIR FEASIBILITY}

Sa'avu and co-authors also addressed maintenance of equipment necessary for neonatal oxygen therapy. ${ }^{16}$ They found that, amongst the five district hospitals in Papua New Guinea, most of the equipment being used before the intervention was donated and therefore, difficult to maintain. ${ }^{16}$ No other publications addressed the maintenance or repair of equipment necessary for neonatal oxygen therapy.

\section{B) CLINICAL PRACTICE OF NEONATAL OXYGEN THERAPY}

We explored four issues under the process dimension of the Donabedian framework; (a) the recognition of the need for initiation of oxygen, often accomplished through clinical signs or oxygen saturation (SpO2) monitoring; (b) the frac- tion of inspired oxygen (FiO2) used; (c) the monitoring of ongoing delivery of oxygen; and (d) the cessation of oxygen therapy (Table 2).

\section{CLINICAL PRACTICE: INITIATION OF OXYGEN THERAPY}

One study provided information on the initiation of oxygen therapy. Heuvel and colleagues' study at Queen Elizabeth Central Hospital in Malawi described the usage of a newly installed CPAP machine, consisting of a compressor, oxygen concentrator, water bottle to control the pressure and binasal prongs. ${ }^{11}$ The study found that in the first seven weeks of use 11 neonates were treated with CPAP therapy, of whom only five met the inclusion criteria. ${ }^{11}$ Additionally, 20 other neonates met eligibility requirements for the usage of CPAP, but did not receive the therapy due to unavailability of device or clinical error. ${ }^{11}$ The study also notes that after this initial introductory period the frequency of use declined even further. ${ }^{11}$

\section{CLINICAL PRACTICE: FRACTION OF INSPIRED OXYGEN (FIO2)}

One study provided information on FiO2 in routine neonatal oxygen therapy. ${ }^{21}$ Rohit et al., in an observational study of different methods of ventilation at an NICU in India, described a practice of starting FiO2 for nasal CPAP at 0.4 for neonates with respiratory distress receiving nasal CPAP oxygen therapy at the onset of the therapy. ${ }^{21}$ 


\section{CLINICAL PRACTICE: MONITORING OF OXYGEN THERAPY}

Two publications provided information on goal oxygen saturation (SpO2) range used to guide oxygen therapy in neonates. ${ }^{24,26}$ Adio et al., in a cohort study that screened premature neonates to determine the incidence and risk factors for the development of retinopathy of prematurity at a teaching hospital in Port Harcourt, Nigeria noted that neonates were treated with oxygen therapy at a goal range of $90-95 \%$ SpO2. ${ }^{24}$ Likewise, Sathar et al., in a cohort study of retinopathy of prematurity development in premature neonates, described a goal $\mathrm{SpO} 2$ of $93-95 \%$ and indicated that monitoring with pulse oximetry was continuous. ${ }^{26}$

\section{CLINICAL PRACTICE: CESSATION OF OXYGEN THERAPY}

No publications provide information on the clinical guidelines or practices leading to the cessation of oxygen therapy in neonates.

\section{C) OUTCOMES OF NEONATAL OXYGEN THERAPY}

Most of the recent peer-reviewed literature providing information on the outcomes associated with neonatal oxygen therapy focuses on the development of retinopathy of prematurity and its association to oxygen exposure (Table 3).

\section{ADVERSE OUTCOMES: RETINOPATHY OF PREMATURITY (ROP)}

Fourteen publications provided information on the relationship between neonatal oxygen therapy and retinopathy of prematurity, with eleven of those publications describing studies in South Asia, one in Egypt, and another two in Nigeria. ${ }^{7,21,24-36}$ All of these publications reflected studies conducted at tertiary care hospitals and described neonates who had been given care in their facility. $7,21,24-34,36$

Eleven out of the fourteen publications described cohort studies that selected a group of neonates with risk factors for retinopathy of prematurity and attempted to describe the prevalence and risk factors for the development of retinopathy of prematurity. ${ }^{21,24,26,27,29-34,36}$ The selection criteria for the neonates varied from study to study, but generally involved gestational age and weight criteria for screening, and then included other neonates who met other risk factors for retinopathy of prematurity. ${ }^{21,24,26,27,29-34,36}$ Clinical information on the monitoring of oxygen therapy in neonates was not provided in nine out of the eleven publications, while Sathar et al. and Adio et al. each described continuous monitoring of $\mathrm{SpO} 2$ on a pulse oximeter with a target SpO2 under 95\%. ${ }^{21,24,26,27,29-34,36}$ Of these eleven publications, four found oxygen therapy to be significantly associated with retinopathy of prematurity, and six found oxygen therapy to be a risk factor for the development of retinopathy of prematurity. ${ }^{21,24,26,27,29,31-34,36}$ The eleventh study found oxygen therapy to be associated with retinopathy of prematurity, $P=0.11$, but not significantly so. ${ }^{30}$ The incidence of retinopathy of prematurity ranged from $11.9 \%$ to $25 \%$ in South Asia, $15 \%$ and $47.2 \%$ in the two publications that described hospitals in Nigeria, and $19.2 \%$ in the study from
Egypt. ${ }^{21,24,26,27,29-34,36}$ Three publications, all studies conducted in India, calculated odds ratios for the development of retinopathy of prematurity in the presence of neonatal oxygen therapy, and found odds ratios of 1.89 (confidence interval $\mathrm{CI}=1.06-3.39)$, Chaudhari et al., 2.4 (CI=1.1-5.4), P.S. Kumar, M. J*. et al*., and 2.042 (CI=1.221-3.416), Sathar et al. ${ }^{23,26,31}$

The objective of the other three publications, including two case series and one case control study, was to describe the outcomes or characteristics of the neonates who had already developed the disease. ${ }^{7,25,28}$ In contrast to the cohort studies above, these studies described children who had been treated at an outside hospital and then were referred to their tertiary care facility after having developed retinopathy of prematurity. $7,25,28$ All three of the publications indicated that all children who developed retinopathy of prematurity had received unmonitored oxygen therapy at the original treating hospital, and postulated that oxygen therapy is at least a contributing factor in the development of retinopathy of prematurity in the neonates studied. $7,25,28$

\section{DISCUSSION}

Maintenance and indirect costs associated with the procurement of oxygen may constitute significant barriers to oxygen supply. ${ }^{16}$ When oxygen is available in facilities, neonates with potential to benefit might not receive therapy in some facilities because of limited equipment, shortage of staff, and unfamiliarity with the technology. ${ }^{11}$ When neonates receive oxygen therapy, the most common regulating or conditioning equipment described in the literature is CPAP and the patient interface used is variable, but is often some form of nasal prongs. ${ }^{11,12,17-23}$ While pulse oximeters are used for monitoring of neonatal oxygen therapy in many healthcare facilities, there are examples within the published literature of hospitals delivering neonatal oxygen therapy without necessary monitoring equipment. ${ }^{11,12,15-17,21,23-26}$ Oxygen blenders, which are necessary to titrate the fraction of inspired oxygen (FiO2) and by extension the patient's oxygen saturation (SpO2), were only described briefly in one study. ${ }^{20}$

There is a paucity of data on effectiveness of neonatal oxygen therapy in LMICs as currently practiced, as well as important side effects such as bronchopulmonary dysplasia. However, some findings were present in the literature including the suggestion that the usage of a bCPAP device with oxygen as opposed to oxygen therapy through a standard flow nasal cannula or nasal prong in the treatment of neonates with respiratory distress may significantly increase survival for affected neonates. ${ }^{13}$ Additionally, oxygen therapy was shown by many publications to be associated with development of retinopathy of prematurity and its prevalence among low birth weight and early gestational age neonates and other neonates with risk factors may range from $11.9-47.2 \% .{ }^{21,24,26,27,29-34,36}$

Our findings reinforce the conclusions of Graham et al. that programmatic initiatives for improving oxygen delivery require multi-level and multi-disciplinary interventions addressing all dimensions of oxygen therapy quality. ${ }^{37}$ A specific issue that is deserving of attention is the availability of monitoring equipment appropriate for neonates. Pulse 
Table 3. Outcomes of neonatal oxygen therapy summary table

\begin{tabular}{|c|c|c|c|c|c|c|}
\hline $\begin{array}{l}\text { Author, } \\
\text { Reference } \\
\text { Year, } \\
\text { Location }\end{array}$ & $\begin{array}{l}\text { Health Care } \\
\text { Facility }(n=) \text {, } \\
\text { Study } \\
\text { Population }\end{array}$ & $\begin{array}{l}\text { Study } \\
\text { Objective to } \\
\text { Describe }\end{array}$ & Study Type & $\begin{array}{l}\text { Oxygen } \\
\text { Therapy } \\
\text { Clinical } \\
\text { Information } \\
\text { Given }\end{array}$ & $\begin{array}{l}\text { Incidence } \\
\text { within the } \\
\text { entire } \\
\text { population } \\
\text { screened }\end{array}$ & $\begin{array}{l}\text { Relationship } \\
\text { to Oxygen } \\
\text { Therapy }\end{array}$ \\
\hline \multicolumn{7}{|c|}{ Retinopathy of Prematurity: } \\
\hline \multicolumn{7}{|c|}{ Southern Asia } \\
\hline $\begin{array}{l}\text { Adhikari, } \\
2008, \\
\text { Nepal }\end{array}$ & $\begin{array}{l}\text { Tertiary Care } \\
\text { Center (1). } \\
\text { Neonates: GA } \\
\leq 34 \text { weeks } \\
\text { and/or BW } \leq \\
1700 \text { gm and } \\
\text { who attended } \\
\text { the follow up } \\
\text { visits }\end{array}$ & $\begin{array}{l}\text { Incidence, risk } \\
\text { factors for } \\
\text { ROP }\end{array}$ & $\begin{array}{l}\text { Prospective } \\
\text { Cohort Study }\end{array}$ & None & $\begin{array}{l}14 / 55 \\
(25.45 \%)\end{array}$ & $\begin{array}{l}\text { Oxygen } \\
\text { administration } \\
\text { was } \\
\text { significantly } \\
\text { associated } \\
\text { with incidence } \\
\text { of ROP } \\
(P<.01) \text {. }\end{array}$ \\
\hline $\begin{array}{l}\text { Chaudhari, } \\
\text { 2008, India }\end{array}$ & $\begin{array}{l}\text { Tertiary Care } \\
\text { Center - } \\
\text { NICU (1). } \\
\text { Neonates: GA } \\
\leq 32 \text { weeks } \\
\text { and BW < } \\
1500 g \text { OR GA } \\
>32 \text { weeks } \\
\text { and BW } \geq \\
1500 g \text { with } \\
\text { additional risk } \\
\text { factors for } \\
\text { ROP }\end{array}$ & $\begin{array}{l}\text { Risk Factors of } \\
\text { ROP }\end{array}$ & $\begin{array}{l}\text { Prospective } \\
\text { Cohort Study }\end{array}$ & None & $\begin{array}{l}123 / 552 \\
(22.3 \%)\end{array}$ & $\begin{array}{l}\text { Oxygen } \\
\text { therapy a risk } \\
\text { factor for ROP } \\
\text { development, } \\
\text { Univariate } \\
\text { odds ratio = } \\
2.75 \\
(1.81-4.19), \\
\text { Multivariate } \\
\text { analysis } \\
\text { OR=1.89 } \\
(1.06-3.39), \\
P=.031\end{array}$ \\
\hline $\begin{array}{l}\text { Gayathri, } \\
\text { 2015, India }\end{array}$ & $\begin{array}{l}\text { Tertiary Care } \\
\text { Hospital (1). } \\
\text { Neonates: GA } \\
\leq 34 \text { weeks } \\
\text { and birth } \\
\text { weight } \leq 1750 \\
\text { g OR GA = } \\
34-36 \text { weeks } \\
\text { and BW = } \\
\text { 1750-2000g } \\
\text { with } \\
\text { additional risk } \\
\text { factors for } \\
\text { ROP }\end{array}$ & $\begin{array}{l}\text { Incidence and } \\
\text { Risk Factors } \\
\text { for ROP }\end{array}$ & $\begin{array}{l}\text { Prospective } \\
\text { Cohort Study }\end{array}$ & None & $\begin{array}{l}21 / 100 \\
(21 \%)\end{array}$ & $\begin{array}{l}\text { Oxygen } \\
\text { therapy a } \\
\text { significant risk } \\
\text { factor for ROP } \\
(P=0.013)\end{array}$ \\
\hline $\begin{array}{l}\text { Jamil, } \\
2015, \\
\text { Pakistan }\end{array}$ & $\begin{array}{l}\text { Referral } \\
\text { Hospital (1). } \\
\text { Neonates: GA } \\
<37 \text { weeks } \\
\text { and BW < } \\
2000 g \text { OR } \\
\text { those who } \\
\text { were } \\
\text { considered } \\
\text { high risk for } \\
\text { ROP }\end{array}$ & $\begin{array}{l}\text { Demographic } \\
\text { and Clinical } \\
\text { Features of } \\
\text { ROP }\end{array}$ & $\begin{array}{l}\text { Prospective } \\
\text { Cohort Study }\end{array}$ & None & $\begin{array}{l}70 / 285 \\
(24.6 \%)\end{array}$ & $\begin{array}{l}\text { The study } \\
\text { identified } \\
\text { supplemental } \\
\text { oxygen } \\
\text { therapy as a } \\
\text { risk factor for } \\
\text { ROP. }\end{array}$ \\
\hline $\begin{array}{l}\text { Rohit, } \\
\text { 2014, India }\end{array}$ & $\begin{array}{l}\text { University } \\
\text { Hospital (1). } \\
\text { Neonates: } \\
\text { BW < 1800 g }\end{array}$ & $\begin{array}{l}\text { Incidence and } \\
\text { Risk Factors }\end{array}$ & $\begin{array}{l}\text { Prospective } \\
\text { Cohort Study }\end{array}$ & None & $\begin{array}{l}38 / 278 \\
(13.67 \%)\end{array}$ & $\begin{array}{l}\text { Association } \\
\text { found } \\
\text { between } \\
\text { prolonged } \\
\text { oxygen } \\
\text { exposure (>7 } \\
\text { days) and ROP } \\
\text { on univariate } \\
\text { analysis. }\end{array}$ \\
\hline $\begin{array}{l}\text { Kumar, } \\
\text { 2011, India }\end{array}$ & $\begin{array}{l}\text { Tertiary Care } \\
\text { Hospital (1). }\end{array}$ & $\begin{array}{l}\text { Risk Factors of } \\
\text { ROP needing }\end{array}$ & $\begin{array}{l}\text { Retrospective } \\
\text { Cohort Study }\end{array}$ & None & $\begin{array}{l}84 / 704 \\
(11.9 \%)\end{array}$ & $\begin{array}{l}\text { Use of oxygen } \\
\text { therapy was }\end{array}$ \\
\hline
\end{tabular}




\begin{tabular}{|c|c|c|c|c|c|c|}
\hline $\begin{array}{l}\text { Author, } \\
\text { Reference } \\
\text { Year, } \\
\text { Location }\end{array}$ & $\begin{array}{l}\text { Health Care } \\
\text { Facility }(n=) \text {, } \\
\text { Study } \\
\text { Population }\end{array}$ & $\begin{array}{l}\text { Study } \\
\text { Objective to } \\
\text { Describe }\end{array}$ & Study Type & $\begin{array}{l}\text { Oxygen } \\
\text { Therapy } \\
\text { Clinical } \\
\text { Information } \\
\text { Given }\end{array}$ & $\begin{array}{l}\text { Incidence } \\
\text { within the } \\
\text { entire } \\
\text { population } \\
\text { screened }\end{array}$ & $\begin{array}{l}\text { Relationship } \\
\text { to Oxygen } \\
\text { Therapy }\end{array}$ \\
\hline & $\begin{array}{l}\text { Neonates: GA } \\
\leq 32 \text { weeks or } \\
\mathrm{BW} \leq 1500 \mathrm{~g} \\
O R \mathrm{GA}= \\
33-34 \text { weeks } \\
\text { and BW = } \\
1501-1800 \mathrm{~g} \\
\text { with risk } \\
\text { factors g with } \\
\text { risk factors }\end{array}$ & laser therapy & & & & $\begin{array}{l}\text { associated } \\
\text { with the } \\
\text { development } \\
\text { of ROP. } \\
\text { OR=2.4 } \\
(1.1-5.4) \\
P=.03\end{array}$ \\
\hline $\begin{array}{l}\text { Pal, 2015, } \\
\text { India }\end{array}$ & $\begin{array}{l}\text { University } \\
\text { Hospital } \\
\text { NICU (1). } \\
\text { Neonates: GA } \\
\leq 35 \text { wks }\end{array}$ & $\begin{array}{l}\text { Incidence and } \\
\text { Risk Factors of } \\
\text { ROP }\end{array}$ & $\begin{array}{l}\text { Prospective } \\
\text { Cohort Study }\end{array}$ & None & $\begin{array}{l}12 / 50 \\
(24 \%)\end{array}$ & $\begin{array}{l}\text { Oxygen } \\
\text { therapy } \\
\text { determined to } \\
\text { be a } \\
\text { significant risk } \\
\text { factor } \\
(P<.001) \text { for } \\
\text { development } \\
\text { of ROP }\end{array}$ \\
\hline $\begin{array}{l}\text { Sathar, } \\
2017 \text {, India }\end{array}$ & $\begin{array}{l}\text { Referral } \\
\text { Hospital (1). } \\
\text { Neonates: GA } \\
\leq 32 \text { weeks or } \\
\text { BW } \leq 1500 \mathrm{~g}\end{array}$ & $\begin{array}{l}\text { Describe the } \\
\text { Risk Factors of } \\
\text { ROP }\end{array}$ & $\begin{array}{l}\text { Prospective } \\
\text { Cohort Study }\end{array}$ & $\begin{array}{l}\text { SpO2 was } \\
\text { monitored } \\
\text { and kept } \\
\text { between } \\
\text { 93-95\% }\end{array}$ & $\begin{array}{l}203 / 812 \\
(25 \%)\end{array}$ & $\begin{array}{l}\text { Oxygen } \\
\text { therapy a } \\
\text { significant risk } \\
\text { factor for } \\
\text { ROP, } P=.007 \text {; } \\
\text { OR }=2.042 \\
(1.221-3.416)\end{array}$ \\
\hline $\begin{array}{l}\text { Shah, } \\
2009 \text {, India }\end{array}$ & $\begin{array}{l}\text { Tertiary Care } \\
\text { Eye Referral } \\
\text { Hospital (1); } \\
\text { children came } \\
\text { referred from } \\
\text { other } \\
\text { hospitals; } \\
\text { Neonates } \\
\text { born between } \\
\text { July } 2002 \text { and } \\
\text { October } 2007 \\
\text { who } \\
\text { presented to } \\
\text { their hospital } \\
\text { with severe } \\
\text { ROP. }\end{array}$ & $\begin{array}{l}\text { Characteristics } \\
\text { of Neonates } \\
\text { with Severe } \\
\text { ROP }\end{array}$ & $\begin{array}{l}\text { Retrospective } \\
\text { Observational } \\
\text { Study }\end{array}$ & $\begin{array}{l}\text { "Most babies } \\
\text { had received } \\
\text { unmonitored } \\
\text { oxygen } \\
\text { therapy" - } \\
\text { Study did not } \\
\text { quantify the } \\
\text { amount of } \\
\text { children } \\
\text { receiving } \\
\text { unmonitored } \\
\text { oxygen } \\
\text { therapy }\end{array}$ & All & $\begin{array}{l}\text { Oxygen } \\
\text { therapy a } \\
\text { significant risk } \\
\text { factor for } \\
\text { increased } \\
\text { severity of } \\
\text { disease. } \\
P=.0001 \text {. }\end{array}$ \\
\hline $\begin{array}{l}\text { Ahmed, } \\
2008, \\
\text { Bangladesh }\end{array}$ & $\begin{array}{l}\text { Tertiary Care } \\
\text { Hospital with } \\
\text { Special Care } \\
\text { Nursery. } \\
\text { Preterm } \\
\text { infants GA< } \\
33 \text { weeks who } \\
\text { were } \\
\text { admitted for a } \\
\text { trial of topical } \\
\text { emollient } \\
\text { therapy }\end{array}$ & $\begin{array}{l}\text { Description of } \\
\text { Children who } \\
\text { developed } \\
\text { ROP }\end{array}$ & Case Report & $\begin{array}{l}\text { All babies (5) } \\
\text { who were } \\
\text { found to } \\
\text { have ROP } \\
\text { received } \\
\text { poorly } \\
\text { monitored } \\
\text { O2 therapy }\end{array}$ & All & $\begin{array}{l}\text { All cases } \\
\text { found had } \\
\text { been treated } \\
\text { with oxygen } \\
\text { therapy }\end{array}$ \\
\hline $\begin{array}{l}\text { Sanghi, } \\
2014, \text { India }\end{array}$ & $\begin{array}{l}\text { Children with } \\
\text { Aggressive } \\
\text { Posterior } \\
\text { ROP who } \\
\text { were referred } \\
\text { from Level I } \\
\text { and II } \\
\text { nurseries }\end{array}$ & $\begin{array}{l}\text { Report on the } \\
\text { Spectrum and } \\
\text { Outcomes of } \\
\text { Aggressive } \\
\text { Posterior } \\
\text { Retinopathy of } \\
\text { Prematurity }\end{array}$ & $\begin{array}{l}\text { Retrospective } \\
\text { Case Series }\end{array}$ & $\begin{array}{l}\text { All babies } \\
\text { (15) received } \\
\text { supplemental } \\
\text { unmonitored } \\
\text { O2 }\end{array}$ & All & $\begin{array}{l}\text { All cases } \\
\text { found had } \\
\text { been treated } \\
\text { with oxygen } \\
\text { therapy }\end{array}$ \\
\hline
\end{tabular}




\begin{tabular}{|c|c|c|c|c|c|c|}
\hline $\begin{array}{l}\text { Author, } \\
\text { Reference } \\
\text { Year, } \\
\text { Location }\end{array}$ & $\begin{array}{l}\text { Health Care } \\
\text { Facility }(n=), \\
\text { Study } \\
\text { Population }\end{array}$ & $\begin{array}{l}\text { Study } \\
\text { Objective to } \\
\text { Describe }\end{array}$ & Study Type & $\begin{array}{l}\text { Oxygen } \\
\text { Therapy } \\
\text { Clinical } \\
\text { Information } \\
\text { Given }\end{array}$ & $\begin{array}{l}\text { Incidence } \\
\text { within the } \\
\text { entire } \\
\text { population } \\
\text { screened }\end{array}$ & $\begin{array}{l}\text { Relationship } \\
\text { to Oxygen } \\
\text { Therapy }\end{array}$ \\
\hline $\begin{array}{l}\text { Adio, 2014, } \\
\text { Nigeria }\end{array}$ & $\begin{array}{l}\text { Tertiary Care } \\
\text { Hospital (1). } \\
\text { Neonates: GA } \\
<32 \\
\text { completed } \\
\text { weeks and } \\
\text { BW }<1500 \mathrm{~g}\end{array}$ & $\begin{array}{l}\text { Incidence and } \\
\text { Risk Factors } \\
\text { for ROP }\end{array}$ & $\begin{array}{l}\text { Prospective } \\
\text { Cohort Study }\end{array}$ & $\begin{array}{l}\text { Oxygen } \\
\text { therapy } \\
\text { monitored on } \\
\text { pulse } \\
\text { oximetry, } \\
\text { kept } \\
\text { between } \\
90-95 \%\end{array}$ & $\begin{array}{l}25 / 53 \\
(47.2 \%)\end{array}$ & $\begin{array}{l}\text { Oxygen } \\
\text { therapy is } \\
\text { found to be a } \\
\text { significant risk } \\
\text { factor for the } \\
\text { development } \\
\text { of ROP } P=.01 \text {. }\end{array}$ \\
\hline $\begin{array}{l}\text { Fajolu, } \\
2015, \\
\text { Nigeria }\end{array}$ & $\begin{array}{l}\text { University } \\
\text { Teaching } \\
\text { Hospital (1). } \\
\text { Neonates: GA } \\
<32 \text { weeks } \\
\text { and BW } \leq \\
1500 \mathrm{~g}\end{array}$ & $\begin{array}{l}\text { Incidence and } \\
\text { Risk Factors } \\
\text { Of ROP }\end{array}$ & $\begin{array}{l}\text { Prospective } \\
\text { Cohort Study }\end{array}$ & None & $\begin{array}{l}12 / 80 \\
(15 \%)\end{array}$ & $\begin{array}{l}\text { Oxygen } \\
\text { therapy was } \\
\text { not } \\
\text { significantly } \\
\text { associated } \\
\text { with ROP } \\
P=.11 \text {. }\end{array}$ \\
\hline \multicolumn{7}{|c|}{ Northern Africa: } \\
\hline $\begin{array}{l}\text { Hakeem, } \\
2012, \\
\text { Egypt }\end{array}$ & $\begin{array}{l}\text { University } \\
\text { Hospital (1). } \\
\text { Neonates: GA } \\
<32 \text { weeks } \\
\text { and BW } \leq \\
1500 \mathrm{~g} \text { OR GA } \\
>32 \text { weeks or } \\
\text { BW > 1500g } \\
\text { and exposed } \\
\text { to oxygen } \\
\text { therapy for } \\
\text { more than } 7 \\
\text { days }\end{array}$ & $\begin{array}{l}\text { Risk Factors of } \\
\text { ROP }\end{array}$ & $\begin{array}{l}\text { Prospective } \\
\text { Cohort Study }\end{array}$ & None & $\begin{array}{l}33 / 172 \\
(19.2 \%)\end{array}$ & $\begin{array}{l}\text { A significant } \\
\text { relationship } \\
\text { was found } \\
\text { between the } \\
\text { occurrence of } \\
\text { ROP and } \\
\text { oxygen } \\
\text { therapy } \\
(P=0.018) .\end{array}$ \\
\hline
\end{tabular}

GA - gestational age, BW - birth weight, gm - grams, OR - odds ratio, ROP - retinopathy of prematurity

oximeters available in the facility might not be useful in neonatal care if the probe size needed for neonates is not provided. ${ }^{16}$ Additionally, the need for constant SpO2 monitoring, in order to avoid dangerous spikes in blood oxygen concentrations, as well as the possibility of the development of hypoxia induced by nasal obstruction places a high demand on clinical personnel administering the therapy. Once the right equipment is in place, clear guidelines are needed to direct the clinical application of neonatal oxygen therapy and quality improvement strategies are needed to ensure consistent application of the guideline. An issue not found in this review, though observed in health facilities by multiple co-authors of this paper, is a system of payas-you-go access to oxygen therapy for children in low and middle-income countries. Out-of-pocket payment by families, coupled with the fact that oxygen therapy is often relatively expensive in such settings, poses a further barrier to providing quality oxygen therapy in neonates for an adequate duration and creates an inequitable distribution of potentially life-saving therapy.

It appears that rates of retinopathy of prematurity among neonates of matched gestational age in low and low middle income countries are markedly higher than the incidence rates reported in high income countries. ${ }^{26,27,36,38,39}$ While this difference may reflect the unmonitored use of oxygen therapy or variable practice with respect to target saturations, it also raises a question as to whether infants in low and middle-income countries might be more vulnerable to toxicities associated with exposure to therapeutic oxygen. Co-morbidities present in middle and low-income countries including malnutrition and increased risk of infection may potentiate risks of oxygen exposure, raising further concerns that vulnerable organ systems, including the cardiovascular system, lungs and brain, might also be at greater risk of toxicity with oxygen therapy.

This review also highlights a number of gaps in the literature and opportunities for further study (Table 4), including the paucity of systematic data that can guide policy, global programming initiatives, and accountability. Most of the publications reviewed did not provide direct estimates across health systems of neonatal oxygen therapy equipment or related clinical practice. The one study that does, the 2010 Kenyan Service Provision Assessment, provides an estimate of the prevalence of neonatal oxygen therapy within the country, but the loose criteria of having either an oxygen concentrator, oxygen cylinder, or oxygen distribution system at the time of assessment does not go far enough to assess if all of the necessary equipment is available for the proper and safe provision of oxygen therapy at these facilities. ${ }^{14}$ Surprisingly, of the USAID Service Provision Assessment reports reviewed, Kenya was the only report that provided information on neonatal-specific indicators. Future reports would benefit from standard neonatal-specific assessments and tabulations given that neona- 
Table 4. Opportunities for further study in Neonatal Oxygen Therapy in LIC/LMIC

Physical equipment

Clinical practice

\begin{tabular}{|c|c|c|c|c|c|c|c|}
\hline & $\begin{array}{l}\text { Availability } \\
\text { of oxygen }\end{array}$ & $\begin{array}{l}\text { Materials } \\
\text { used to } \\
\text { modify } \\
\text { oxygen flow/ } \\
\text { content/ } \\
\text { pressure }\end{array}$ & $\begin{array}{l}\text { Patient } \\
\text { interface } \\
\text { devices }\end{array}$ & $\begin{array}{l}\text { Monitoring } \\
\text { equipment }\end{array}$ & $\begin{array}{l}\text { 'Maintenance } \\
\text { and Repair } \\
\text { Feasibility }\end{array}$ & Initiation & Monitoring \\
\hline $\begin{array}{l}\text { Systematic } \\
\text { Data }\end{array}$ & $\begin{array}{l}\text { Availability } \\
\text { of oxygen } \\
\text { in } \\
\text { institutions } \\
\text {-payment } \\
\text { system }\end{array}$ & $\begin{array}{l}\text { Oxygen } \\
\text { blender } \\
\text { availability }\end{array}$ & & $\begin{array}{l}\text { Monitoring } \\
\text { equipment } \\
\text { availability } \\
\text {-Neonatal } \\
\text { pulse } \\
\text { oximetry } \\
\text { probes }\end{array}$ & & & $\begin{array}{l}\text { Frequency of } \\
\text { SpO2 } \\
\text { monitoring }\end{array}$ \\
\hline $\begin{array}{l}\text { Institutional } \\
\text { Level Data }\end{array}$ & $\begin{array}{l}\text { Payment } \\
\text { systems } \\
\text { for } \\
\text { neonatal } \\
\text { oxygen } \\
\text { therapy }\end{array}$ & $\begin{array}{l}\text { Low-cost } \\
\text { oxygen } \\
\text { blender } \\
\text { development }\end{array}$ & & & $\begin{array}{l}\text { Maintenance } \\
\text { and repair } \\
\text { plan for } \\
\text { oxygen } \\
\text { therapy } \\
\text { equipment }\end{array}$ & $\begin{array}{l}\text { Quality } \\
\text { improvement } \\
\text { initiatives to } \\
\text { assure } \\
\text { optimal } \\
\text { numbers of } \\
\text { neonates are } \\
\text { treated }\end{array}$ & $\begin{array}{l}\text { Quality } \\
\text { improvement } \\
\text { initiative to } \\
\text { assure } \\
\text { effective } \\
\text { monitoring } \\
\text { of therapy }\end{array}$ \\
\hline Guidelines & \multicolumn{5}{|c|}{ List of equipment necessary to safely administer neonatal oxygen therapy } & $\begin{array}{l}\text { Optimal } \\
\text { initiation } \\
\text { criteria for } \\
\text { oxygen } \\
\text { therapy in } \\
\text { neonates }\end{array}$ & $\begin{array}{l}\text { Frequency of } \\
\text { SpO2 } \\
\text { monitoring }\end{array}$ \\
\hline
\end{tabular}

LIC - low-income country, LMIC - low- and middle-income country, SpO2 - oxygen saturation, ROP - retinopathy of prematurity

tal mortality represents a growing fraction of under-five deaths as a whole. For oxygen therapy specifically a reasonable assessment of a facility's readiness to administer neonatal oxygen therapy might include questions on: (a) availability of a source of oxygen (i.e. oxygen cylinders, oxygen concentrators, etc.), (b) availability of patient monitoring equipment during oxygen therapy including neonatal specific probe availability if using a pulse oximeter and a reported frequency of monitoring during therapy, and (c) questions on the availability of oxygen blenders in order to be able to titrate the amount of oxygen given.

Another gap is the paucity of information about oxygen blenders in the literature, with only one study mentioning their availability. While, traditionally, oxygen blenders have been cost-prohibitive in resource-limited settings, recent technological advances in the creation of low-cost oxygen blenders may make them more widely available and published literature on their availability and use will likely be important going forward. ${ }^{40}$ Additionally, there are no reports of the specific barriers faced by clinicians in appropriately initiating or ceasing neonatal oxygen therapy. Finally, and of significance, is the paucity of reports of systemwide assessments of availability and usage of pulse oximeters to monitor neonatal oxygen therapy and the multiple indications that facilities are currently giving oxygen without pulse oximeter monitoring. The ethical commitment to 'do no harm' and the well-established side effects of unmonitored oxygen therapy make large-scale monitoring and evaluation of use of pulse oximeters, oxygen blenders, and other important equipment a priority.

There were several limitations to our review. First, we conducted our literature search only in English and, therefore, have excluded other neonatal oxygen therapy reports published in Spanish, French, Arabic, and other languages. Second, many of the publications in this review were not focused on the review objectives, and only provided incidental information on the quality of neonatal oxygen therapy. Third, the health care facilities that are represented in this paper may not be a representative sample to provide a picture of the quality of neonatal oxygen therapy in low and low-middle income countries. Published literature inherently reflects more advanced care as authors are more likely to be in academic settings, and therefore our review would be more likely to under-report the burden of unmonitored or inappropriate oxygen use. This is particularly relevant with respect to the generalizability of outcomes of oxygen therapy. Most publications that described retinopathy of prematurity incidence in neonates treated at tertiary care facilities were assumed to have received optimal clinical practice in the provision of oxygen therapy, ${ }^{21,24,27,29-34,36}$ while other publications that described the outcomes of neonates treated at health care facilities of a lower tier that 
were later referred to a tertiary care facility often described unmonitored oxygen therapy as the primary driver in the development of retinopathy of prematurity. ${ }^{7,25,28}$ Fourth, the scope of our review did not include other important resources such as the WHO Service Availability and Readiness Assessments (SARA) or country-level Emergency Obstetric and Newborn Care (EmONC) assessments.

\section{CONCLUSIONS}

Maintenance and indirect costs associated with the procurement of oxygen may constitute barriers to oxygen supply. ${ }^{16}$ When neonates receive oxygen therapy, the most common regulating or conditioning equipment described in the literature is continuous positive airway pressure devices, and the patient interface used is variable, but is often some form of nasal prongs. ${ }^{11,12,17-22}$ Pulse oximeters used for monitoring of oxygen therapy are available in healthcare facilities, but there is very little known about the frequency of that monitoring and there are indications that hospitals deliver neonatal oxygen therapy without necessary monitoring equipment at all. ${ }^{11,12,15-17,21,23-26}$ Oxygen therapy is associated with the development of retinopathy of prematurity and its prevalence among low birth weight and early gestational age neonates and other neonates with risk factors may range from 11.9-47.2\%, $21,24,26,27,29-34,36$ which appears to be higher than rates in neonates of similar gestational age being treated in high-income countries. ${ }^{26,27,36,38,39}$ Quality improvement initiatives to create standardized guidelines for the appropriate and safe use of neonatal oxygen therapy and address adherence to those guidelines may reduce the burden of associated morbidity and potentially save the lives of neonates in low and lowmiddle income countries.

Disclaimer: The views and opinions expressed in this paper are those of the authors and not necessarily the views and opinions of the United States Agency for International Development.

Funding: No specific funding was required to perform this study.

Authorship contributions: Conceived the study: PKR. Developed framework and organized the search: PKR, MO, JZ. Wrote the first draft of the manuscript: JZ. Wrote and approved the paper: All authors.

Competing interests: The authors completed the Unified Competing Interest form at www.icmje.org/coi disclosure.pdf (available upon request from the corresponding author), and declare no conflicts of interest.

\section{Correspondence to:}

Jon Zelasko BA, MD candidate 2020

Jacobs School of Medicine And Biomedical Sciences University at Buffalo

955 Main Street

Buffalo, New York 14203

United States of America

jzelasko@buffalo.edu 


\section{REFERENCES}

1. Lucia Hug DS, Danzhen Y. Levels and Trends in Child Mortality: Report 2017. New York, NY: United Nations Children's Fund; 2017.

2. World Health Organization. Health and the Millennium Development Goals. Geneva: WHO; 2005. http://www.who.int/hdp/publications/mdg_en.pdf. Accessed June 22, 2018.

3. UNICEF. Statistics by Topic: Maternal Health: Antenatal Care.; 2017. https://data.unicef.org/topic/m aternal-health/antenatal-care/. Accessed June 22, 2018.

4. Duke T, Graham SM, Cherian MN, Ginsburg AS, English M, et al. Oxygen is an essential medicine: A call for international action. Int J Tuberc Lung Dis. 2010;14:1362-18.

5. Walsh BK, Smallwood CD. Pediatric oxygen therapy: A review and update. Respir Care. 2017;62:645-661. doi:10.4187/respcare.05245

6 . The delicate balance: Managing oxygen treatment in neonates. Adv Neonatal Care. 2018;(Suppl 5S):1-12. doi:10.1097/01.ANC.0000547461.94078.09

7. Shah PK, Narendran V, Kalpana N, Gilbert C. Severe retinopathy of prematurity in big babies in India: History repeating itself? Indian journal of pediatrics. 2009;76:801-804.

8. Shah PK, Prabhu V, Karandikar SS, Ranjan R, Narendran V, Kalpana N. Retinopathy of prematurity: Past, present and future. World Journal of Clinical Pediatrics. 2016;5:35-46. doi:10.5409/wjcp.v5.i1.35

9. USAID. SPA Overview. https://dhsprogram.com/Wh at-We-Do/Survey-Types/SPA.cfm. Accessed June 22, 2018 .

10. Donabedian A. The quality of care. How can it be assessed? JAMA. 1988;260:1743-1748. doi:10.1001/ja $\underline{\text { ma.1988.03410120089033 }}$

11. Heuvel MVD, Mittermayer K, Rylance S, Couperus A, Heikens GT, Bandsma RHJ. Introduction of bubble CPAP in a teaching hospital in Malawi. Ann Trop Paediatr. 2011;31:59-65. doi:10.1179/1465328110Y.00 $\underline{00000001}$

12. Hundalani SG, Richards-Kortum R, Oden M, Kawaza K, Gest A, Molyneux E. Development and validation of a simple algorithm for initiation of CPAP in neonates with respiratory distress in Malawi. Arch Dis Child Fetal Neonatal Ed. 2015;100(4):F332-F336. doi:10.1136/archdischild-2014-308082
13. Kawaza K, Machen HE, Brown J, et al. Efficacy of a low-cost bubble CPAP system in treatment of respiratory distress in a neonatal ward in Malawi. Baud O, ed. PLoS ONE. 2014;9(1):e86327. doi:10.137 1/journal.pone.0086327

14. National Coordinating Agency for Population and Development (Kenya), Ministry of Medical Services (Kenya), Ministry of Public Health and Sanitation (Kenya), National Bureau of Statistics (Kenya), ICF Macro. Kenya Service Provision Assessment Survey 2010. Nairobi, Kenya: National Coordinating Agency for Population and Development, Ministry of Medical Services, Ministry of Public Health and Sanitation, Kenya National Bureau of Statistics, and ICF Macro. 2011.

15. Sen A, Mahalanabis D, Singh AK, Som TK, Bandyopadhyay S. Impact of a district level sick newborn care unit on neonatal mortality rate: 2-year follow-up. J Perinatol. 2009;29:150-155. doi:10.1038/i p.2008.177

16. Sa'avu M, Duke T, Matai S. Improving paediatric and neonatal care in rural district hospitals in the highlands of Papua New Guinea: A quality improvement approach. Paediatrics and International Child Health. 2014;34:75-83. doi:10.1179/2046905513 Y.0000000081

17. Bhatti A, Khan J, Murki S, Sundaram V, Saini SS, Kumar P. Nasal Jet-CPAP (variable flow) versus Bubble-CPAP in preterm infants with respiratory distress: An open label, randomized controlled trial. J Perinatol. 2015;35:935-940. doi:10.1038/jp.2015.98

18. Kandraju H, Murki S, Subramanian S, Gaddam P, Deorari A, Kumar P. Early Routine versus Late Selective Surfactant in Preterm Neonates with Respiratory Distress Syndrome on Nasal Continuous Positive Airway Pressure: A Randomized Controlled Trial. Neonatology. 2013;103:148-154. doi:10.1159/00 $\underline{0345198}$

19. Koti J, Murki S, Gaddam P, Reddy A, Reddy MD. Bubble CPAP for respiratory distress syndrome in preterm infants. Indian pediatrics. 2010;47:139-143. $\underline{\text { doi:10.1007/s13312-010-0021-6 }}$

20. Osman M, Elsharkawy A, Abdel-Hady H. Assessment of pain during application of nasalcontinuous positive airway pressure and heated, humidified high-flow nasal cannulae in preterm infants. Journal of Perinatology. 2015;35:263-267. do i:10.1038/ip.2014.206 
21. Rohit K, Talwar R, Soumya S, Premila P, Rakesh Y, Sarthak S. Retinopathy of prematurity in babies weighing < $1800 \mathrm{~g}$; with special reference to babies weighing between 1501 and $1800 \mathrm{~g}$ : An experience from a tertiary care hospital in Delhi. International Journal of Medicine and Public Health. 2014;4:359-363.

22. Tagare A, Kadam S, Vaidya U, Pandit A, Patole S. Bubble CPAP versus ventilator CPAP in preterm neonates with early onset respiratory distress-a randomized controlled trial. J Trop Pediatr. 2013;59:113-119. doi:10.1093/tropei/fms061

23. Das H, Shaikh S, Kella N. Effect of prone versus supine position on oxygen saturation in patients with respiratory distress in neonates. Pakistan Journal of Medical Sciences. 2011;27:1098-1101.

24. Adio AO, Ugwu RO, Nwokocha CG, Eneh AU. Retinopathy of Prematurity in Port Harcourt, Nigeria. ISRN Ophthalmology. 2014;2014:1-6. doi:10.1155/20 $14 / 481527$

25. Sanghi G, Dongra MR, Katoch D, Gupta A. Aggressive posterior retinopathy of prematurity in infants $>/=1500 \mathrm{~g}$ birth weight. Indian J Ophthalmol. 2014;62:254-27. doi:10.4103/0301-4738.128639

26. Sathar A, Shanavas A, Girijadevi PS, Jasmin LB, Sobha Kumar S, Pillai RK. Risk factors of retinopathy of prematurity in a tertiary care hospital in South India. Clinical Epidemiology and Global Health. 2018;6(1):44-49. doi:10.1016/j.cegh.2017.02.002

27. Adhikari S, Badhu BP, Bhatta NK, Rajbhandari RS, Kalakheti BK. Retinopathy of prematurity in a tertiary care hospital in eastern Nepal. JNMA J Nepal Med Assoc. 2008;47:24-27. doi:10.31729/jnma.213

28. Ahmed A, Humaira M, Anwar KS, et al.

Retinopathy of prematurity in Bangladeshi neonates. J Trop Pediatr. 2008;54:333-339. doi:10.1093/tropej/f $\underline{\mathrm{mn} 035}$

29. Chaudhari S, Patwardhan V, Vaidya U, Kadam S, Kamat A. Retinopathy of prematurity in a tertiary care center-Incidence, risk factors and outcome. Indian Pediatr. 2009;46:219-224.

30. Fajolu IB, Rotimi-Samuel A, Aribaba OT, Musa KO, Akinsola FB, et al. Retinopathy of prematurity and associated factors in Lagos, Nigeria. Paediatr Int Child Health. 2015;35:324-328. doi:10.1080/2046904 7.2015.1109277
31. Gayathri S, Mohan BV. Analysis of incidence and risk factors for retinopathy of prematurity among preterm neonates in a tertiary care neonatal unit. Research Journal of Pharmaceutical, Biological and Chemical Sciences. 2015;6:1565-1570.

32. Hakeem AH, Mohamed GB, Othman MF. Retinopathy of prematurity: A study of prevalence and risk factors. Middle East Afr J Ophthalmol. 2012;19:289-294. doi:10.4103/0974-9233.97927

33. Jamil AZ, Tahir MY, Ayub MH, Mirza KA. Features of retinopathy of prematurity in a tertiary care hospital in Lahore. J Pak Med Assoc. 2015;65:156-18.

34. Kumar P, Sankar MJ, Deorari A, et al. Risk factors for severe retinopathy of prematurity in preterm low birth weight neonates. Indian J Pediatr. 2011;78:812-816. doi:10.1007/s12098-011-0363-7

35. World Health Organization. Oxygen therapy for children: a manual for health workers. 2016. http://ap ps.who.int/iris/bitstream/10665/204584/1/978924154 9554_eng.pdf. Accessed June 22, 2018.

36. Pal AK, Sur S, Pal J, Gupta AK. Incidence of retinopathy of prematurity and its association with oxygen therapy in preterm low birth weight babies. Journal of Nepal Paediatric Society. 2015;35:247-252. doi:10.3126/inps.v35i3.12964

37. Graham H, Tosif S, Gray A, Qazi S, Campbell H, Peel D, et al. Providing oxygen to children in hospitals: A realist review. Bull World Health Organ. 2017;95:288-302. doi:10.2471/BLT.16.186676

38. Lad EM, Nguyen TC, Morton JM, Moshfeghi DM. Retinopathy of prematurity in the United States. $\mathrm{Br} \mathrm{J}$ Ophthalmol. 2008;92:320. doi:10.1136/bjo.2007.1262 $\underline{01}$

39. Mitsiakos G, Papageorgiou A. Incidence and factors predisposing to retinopathy of prematurity in inborn infants less than 32 weeks of gestation. Hippokratia. 2016;20:121-16.

40. Daga BS, Joshi H, Gunjal P, Mhatre S. An innovative air-oxygen blender for continuous positive airway pressure support in resource-poor locations: A feasibility study. J Trop Pediatr. 2017;63:269-273. 


\section{SUPPLEMENTARY MATERIALS}

\section{Online Supplementary Document}

Download: https://www.joghr.org/article/12346-neonatal-oxygen-therapy-in-low-and-middle-income-countries-apragmatic-review/attachment/31576.docx 